\title{
Pengaruh Kompetensi SDM, Moralitas, Whistleblowing dan SPI Terhadap Pencegahan Fraud Dalam Pengelolaan Keuangan Desa
}

\author{
Luh Sri Isa Dewi Jayanti ${ }^{1}$ \\ Fakultas Ekonomi dan Bisnis \\ Universitas Udayana, Indonesia. \\ Email: isadewi1996@gmail.com
}

\author{
Ketut Alit Suardana ${ }^{2}$ \\ Fakultas Ekonomi dan Bisnis \\ Universitas Udayana, Indonesia.
}

\begin{abstract}
ABSTRAK
Tujuan penelitian ini adalah untuk menguji secara empiris pengaruh kompetensi sumber daya manusia, moralitas, whistleblowing dan sistem pengendalian internal terhadap pencegahan fraud dalam pengelolaan keuangan desa secara parsial. Penelitian ini dilakukan pada 27 Desa Dinas di Kota Denpasar dengan menggunakan metode total atau sensus. Responden yang digunakan sebanyak 108 orang. Teknik analisis data yang digunakan adalah analisis regresi linier berganda. Hasil penelitian ini menunjukkan bahwa kompetensi sumber daya manusia, moralitas, whistleblowing, dan sistem pengendalian internal berpengaruh positif terhadap pencegahan fraud dalam pengelolaan keuangan desa. Hal ini berarti, dengan adanya kompetensi sumber daya manusia, moralitas yang baik dan sistem pengendalian internal yang kuat, maka dapat mencegah terjadinya tindakan kecurangan dalam pengelolaan keuangan desa.
\end{abstract}

Kata Kunci : Kompetensi Sumber Daya Manusia; Moralitas; Whistleblowing; Sistem Pengendalian Internal; Fraud.

\section{The Effects of HR Competence, Morality, Whistleblowing and ICS to Fraud Prevention in Village Financial Management}

\section{ABSTRACT}

The purpose of this study was to empirically examine the effect of human resource competence, morality, whistleblowing and internal control systems on fraud prevention in partial village financial management. This research was conducted in 27 Dinas Villages in Denpasar City using total or census methods. Respondents used were 108 people. The data analysis technique used is multiple linear regression analysis. The results of this study indicate that human resource competence, morality, whistleblowing, and internal control systems have a positive effect on fraud prevention in village financial management. This means, with the competence of human resources, good morality and a strong internal control system, it can prevent fraud in the management of village finances.

Keywords: Human Resource Competence; Morality; Whistleblowing; Internal Control System; Fraud.

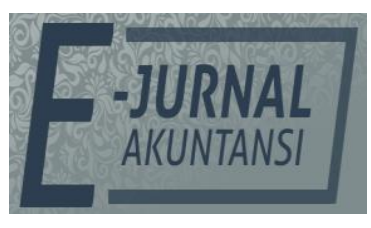

E-JA

e-Jurnal Akuntansi e-ISSN 2302-8556

Vol. 29 No. 3

Denpasar, Desember 2019

Hal. 1117-1131

Artikel masuk: 6 September 2019

Tanggal diterima: 20 Desember 2019 


\section{PENDAHULUAN}

Pemerintah mulai mengalokasikan dana bagi masyarakat desa yang di mulai pada tahun 2015 di seluruh Indonesia. Sesuai dengan amanat Undang-undang Nomor 6 Tahun 2014 Tentang Desa, sumber keuangan pemerintah desa bersumber dari Anggaran Pendapatan Belanja Negara (APBN), alokasi dana desa, pendapatan asli desa, bagi hasil pajak, bagi hasil retribusi, bantuan keuangan Anggaran Pendapatan Belanja Daerah (APBD) provinsi atau kota/kabupaten dan hibah. Dana desa digunakan untuk mendanai penyelenggaraan pemerintahan desa, pelaksanaan pembangunan, dan pemberdayaan masyarakat desa. Dimana tujuan utamanya untuk meningkatkan kesejahteraan masyarakat desa.

Anggaran pendapatan dan Belanja Desa (APB Desa) adalah rencana keuangan tahunan pemerintahan desa. Pengelolaan keuangan desa adalah keseluruhan kegiatan yang meliputi perencanaan, pelaksanaan, penatausahaan, pelaporan, dan pertanggungjawaban keuangan desa. Pemegang Kekuasaan Pelaksana Pengelolaan Keuangan Desa (PPKD) adalah Kepala Desa, Sekretaris Desa sebagai Koordinator PPKD, dan Kaur Keuangan melaksanakan fungsi kebendaharaan. Pengelolaan keuangan desa harus berdasarkan pada prinsip transparansi, akuntabel, partisipatif serta dilakukan dengan tertib dan disiplin anggaran yang telah tertuang dalam Peraturan Menteri Dalam Negeri (Pemendagri) Nomor 20 Tahun 2018 tentang Pengelolaan Keuangan Desa.

Pemendagri Nomor 20 Tahun 2018 tentang Pedoman Pengelolaan Keuangan Desa diharapkan dapat menjadi pedoman dalam pengelolaan keuangan desa karena didalamnya telah mencakup berbagai prosedur pengelolaan keuangan desa mulai dari perencanaan, pelaksanaan, penatausahaan, pelaporan sampai dengan peranggungjawaban. Pemberian alokasi dana desa yang besar memiliki konsekuensi untuk terjadinya kecurangan yang dilakukan oleh pihak-pihak tertentu, khususnya pihak -pihak yang telah dipercaya oleh masyarakat. Kecurangan (fraud) merupakan tindakan yang dilakukan seseorang atau berkelompok secara ilegal baik disengaja maupun tidak disengaja untuk memperoleh keuntungan dengan cara mendapatkan uang, aset dan lain sebagainya sehingga dapat merugikan orang lain atau pihak tertentu (Aini et al., 2017). Fraud menjadi masalah yang harus diperangi bagi sektor publik. Auditor internal yang kompeten dalam mengevaluasi laporan keuangan dan mampu membuat operasi organisasi lebih efektif yang diperlukan untuk meminimalisasi risiko fraud (Hoi dan Robin, 2010).

Berdasarkan hasil pemantauan Indonesia Corruption Watch (ICW) (2018) sejak tahun 2015 hingga semester I 2018, kasus korupsi dana desa mengalami peningkatan dari tahun ke tahun. Dikutip dari sumber Kompas.com, ICW akhir bulan November 2018 lalu melansir data, sejak bergulir tahun 2015 hingga saat ini, dana desa yang sudah dikeluarkan pemerintah berjumlah Rp 186 triliun dan sudah disalurkan ke 74.954 desa di seluruh wilayah Indonesia. Tercatat sedikitnya sudah ada 184 tersangka korupsi nilai kerugian sebesar Rp 40,6 miliar. Pada tahun 2015 terdapat 17 kasus. Pada tahun kedua, jumlahnya meningkat menjadi 41 kasus. Sementara, pada 2017, korupsi dana desa melonjak lebih dari dua kali lipat menjadi 96 kasus. Sementara pada semester I tahun 2018, terdapat 
27 kasus di desa yang semuanya menjadikan anggaran desa sebagai objek korupsi.

Terdapat dugaan penyelewengan dana desa yang terjadi di Kota Denpasar pada tahun 2019. Berdasarkan hasil temuan Penyidik Pidana Khusus (Pidsus) Kejaksaan negeri (Kejari) Denpasar, terdapat dugaan penyalahgunaan dana desa di Desa Dauh Puri Kelod, Kecamatan Denpasar Barat. Dalam kasus ini dari hasil audit evaluasi internal dana APBDesa pada tahun 2017, ditemukan sisa lebih penggunaan anggaran Rp 1,95 miliar. Namun, setelah diminta pertanggungjawaban, perangkat desa yakni Kepala Desa, Kaur Keuangan, dan bagian keuangan tidak bisa menunjukkan jumlah uang sebesar Rp 1,95 miliar (Kompas.com, 2019)

Berdasarkan laporan hasil pengawasan semester II pada tahun 2017 yang dilakukan oleh Badan Pengawasan dan Pembangunan (BPKP) Provinsi Bali, terdapat beberapa masalah pada penyelenggaraan dana desa di Kota Denpasar. Adapun permasalahan yang terjadi, yaitu pada penatausahaan pengelolaan keuangan desa masih terdapat kesalahan dalam implementasi aplikasi Sistem Keuangan Desa (SISKEUDES), terdapat kesalahan penganggaran dalam APBDesa, Badan Usaha Milik Desa (BUM Desa) belum menetapkan anggaran dasar dan anggaran rumah tangga serta belum dilakukannya pencatatan aset atas pekerjaan yang sudah selesai (BPKP, 2018).

Berdasarkan fenomena yang dipaparkan, maka diperlukan suatu cara untuk mengurangi masalah-masalah dari penggunaan dana desa, di samping optimalisasi dari partisipasi masyarakat, suatu bentuk antisipasi untuk mencegah kasus serupa terjadi sangat diperlukan seperti kompetensi sumber daya manusia, moralitas, whistleblowing, dan sistem pengendalian internal.

Menurut penelitian Azlina et al. (2017), potensi sumber daya manusia yang dimiliki desa dalam mengimplementasikan dana desa belum memadai, kurang kompeten dan professional. Namun dapat diatasi dengan konselor desa dan pelatihan regular untuk aparat desa. Dengan adanya profesionalisme dan kompetensi sumber daya manusia dalam pengelolaan keuangan desa, maka sangat diharapkan tujuan ekonomi dan sosial pemerintahan desa dapat tercapai. Oleh karena itu, peran serta pihak-pihak di luar pemerintahan desa dan Badan Permusyawaratan Desa (BPD) seperti tokoh desa, tokoh agama, akademisi, kaum petani, pengusaha desa, serta perwakilan masyarakat lainnya harus bersinergi dan dilibatkan dalam pengelolaan keuangan desa. Menurut Wardani et al. (2017), dalam pengelolaan keuangan daerah yang baik, perangkat desa harus memiliki sumber daya manusia yang berkualitas, didukung dengan latar belakang pendidikan, pelatihan dan mempunyai pengalaman di bidang keuangan. Pendidikan adalah sarana menghasilkan sumber daya manusia berkualitas (Murphy dan Free, 2016), dengan sumber daya manusia yang berkualitas dan berkompeten maka akan menghasilkan laporan keuangan yang berkualitas sehingga pencegahan fraud dapat dihindari. Pengalaman kerja adalah lamanya seseorang dalam memperoleh pengetahuan di bidang tertentu yang dapat meningkatkan sensitivitas terhadap fraud (Kern dan Weber, 2016). Kurangnya kompetensi dalam memahami dan menerapkan logika akuntasi akan memiliki pengaruh terhadap kekeliriuan laporan keuangan yang dibuat dan ketidaksesuaian laporan dengan standar yang telah ditetapkan oleh pemerintah, 
sehingga informasi yang diterima oleh pengguna akan tidak tepat serta akan mempengaruhi keputusan yang akan diambil selanjutnya (Ferina et al., 2014). Penelitian yang dilakukan oleh Ariastini et al. (2017) dan Laksmi et al. (2019) yang menunjukkan bahwa kompetensi sumber daya manusia berpengaruh positif terhadap pencegahan fraud pada pengelolaan dana desa.

Moralitas dapat mempengaruhi etika atau perbuatan yang dilakukan oleh seseorang. Moralitas individu akan berhubungan pada kecenderungan seseorang untuk melakukan kecurangan akuntansi yang dinyatakan oleh Dennyningrat dan Suputra (2018). Menurut Rahimah et al. (2018), individu yang mempunyai tingkat moral yang tinggi akan dapat mencegah terjadinya kecurangan karena individu yang mempunyai moral yang tinggi akan menaati aturan sesuai dengan prinsip-prinsip etika universal, begitupun sebaliknya, individu yang memiliki moral yang rendah cenderung membuat keputusan berdasarkan hak yang diinginkan oleh dirinya sendiri dan tidak menaati peraturan dan kewajiban yang diinginkan oleh dirinya. Pejabat yang memiliki perilaku yang baik akan membuat pengelolaan keuangan berjalan dengan baik, dan begitu sebaliknya (Manosoh, 2016). Donelson et al. (2015) menyebutkan bahwa karyawan yang bekerja di lingkungan yang etis akan melaksanakan pekerjaan sesuai dengan peraturan perundang-undangan yang ditetapkan dan menghindari terjadinya fraud. Penelitian mengenai pengaruh moralitas terhadap pencegahan fraud yaitu penelitian yang dilakukan oleh Laksmi et al. (2019) dan Setiawan (2018) yang menunjukkan bahwa moralitas individu berpengaruh positif terhadap kecurangan akuntansi.

Keberadaan sistem whistleblowing tidak hanya menjadi sarana pelaporan untuk fraud, tetapi juga sebagai bentuk pengawasan. Karyawan takut untuk melakukan fraud karena sistem ini dapat digunakan oleh semua karyawan, sehingga sesama karyawan menjadi saling mengawasi satu sama lain dan takut untuk dilaporkan oleh karyawan lain karena melakukan fraud. Dengan demikian, pemahaman karyawan tentang mekanisme dari whistleblowing membuat karyawan antusias melaporkan kecurangan apa pun kepada otoritas yang berwenang menangani laporan karena sistem pengaduan sudah termasuk perlindungan pengungkap fakta. Ini dapat mencegah fraud yang akan terjadi di perusahaan (Pamungkas et al., 2018). Penelitian yang dilakukan oleh Ariastini et al. (2017) dan Agusyani et al. (2016) juga menemukan di dalam penelitiaannya whistleblowing berpengaruh positif terhadap pencegahan fraud.

Menurut Adi et al. (2016), bahwa tindakan kecurangan (fraud) dalam pengelolaan keuangan desa dapat diminimalisir dan dicegah dengan memperhatikan sistem pengendalian internalnya, sistem pengendalian internal merupakan proses yang dijalankan untuk memberikan keyakinan terhadap pencapaian keandalan laporan keuangan dan keputusan hukum. Committee of Sponsoring Organizations of the Treadway Commission (COSO) (2019:7) menjelaskan terdapat lima indikator yang terdapat dalam sistem pengendaliaan internal yaitu lingkungan pengendalian, penilaian resiko, kegiatan pengendalian, informasi dan komunikasi serta pemantauan pengendalian internal. Fraud juga dipengaruhi oleh adanya peluang sehingga untuk mencegah peluang tersebut diperlukan pengendalian internal yang efektif. Pengendalian internal yang 
efektif akan menghasilkan informasi dan laporan bebas salah saji (Andon et al., 2015).

Penelitian yang dilakukan oleh Ariastini et al. (2017) dan Joseph et al. (2015) yang menujukkan terdapat hubungan positif antara sistem pengendaliaan internal terhadap pencegahan fraud. Penelitian terkait kompetensi sumber daya manusia, moralitas, whistleblowing, dan sistem pengendalian internal terhadap pencegahan fraud telah banyak diteliti, namun sepengetahuan penulis mengenai variabel yang memakai whistleblowing dan responden yang berlatarbelakang Pemerintah Desa sebagai pengelola keuangan desa masih sedikit yang melakukan penelitian karena topik ini termasuk baru. Dengan pertimbangan tersebut, penulis ingin membuktikan pengaruh keempat faktor tersebut terhadap pencegahan fraud dalam pengelolaan keuangan desa di Pemerintah Desa Kota Denpasar sehingga bisa membuktikkan bahwa penelitian yang berlatarbelakang di Pemerintah Desa mempunyai hasil yang sama terhadap yang tidak berlatarbelakang di Pemerintah Desa.

Pengaruh kompetensi sumber daya manusia terhadap pencegahan fraud dalam pengelolaan keuangan desa berkaitan dengan teori keagenan. Teori keagenan memiliki prinsip utama berupa hubungan kerja antara dua pihak yaitu pihak yang memberikan wewenang (principal) dengan pihak yang menerima wewenang (agent) dalam suatu bentuk kerja sama yang dinamakan dengan "nexus of contract" (Jensen and Meckling, 1976). Pemerintah pusat yang mewakili rakyat sebagai principal diasumsikan hanya tertarik kepada laporan keuangan yang angka-angka di pos pembelanjaan sesuai dengan angka-angka yang diajukan dalam proposal dalam dana desa, sementara pihak Pemerintah Desa sebagai agent akan berusaha menyajikan laporan keuangan yang sesuai dengan keinginan pemerintah pusat agar di masa mendatang bisa kembali memperoleh dana karena laporan keuangan memenuhi syarat (Murthy dan Jack, 2017). Kompetensi sumber daya manusia yang berkualitas dari Pemerintah Desa sangat dibutuhkan dalam melaksanakan tanggungjawab tersebut, khususnya dalam pengelolaan keuangan desa, sehingga penggunaan dan pertanggungjawaban dalam pengelolaan keuangan desa sesuai dengan Undang-undang Nomor 6 Tahun 2014 Tentang Desa dan Pemendagri Nomor 20 Tahun 2018 tentang Pengelolaan Keuangan Desa.

Sugiarti dan Yudianto (2017) menjelaskan bahwa kompetensi sumber daya manusia mencakup kapasitasnya yaitu kemampuan seorang individu, suatu organisasi (kelembagaan) atau suatu sistem untuk melaksanakan fungsi-fungsi atau kewenangannya untuk mencapai tujuannya secara efektif dan efisien. Kapasitas harus dilihat sebagai kemampuan untuk mencapai kinerja, menghasilkan output dan income. Jika seseorang memiliki keterampilan, pengetahuan, dan kemampuan yang memadai biasanya mudah mendeteksi adanya kecurangan yang terjadi karena dengan memiliki pengetahuan yang lebih atau melebihi orang yang melakukan fraud, seseorang akan lebih peka terhadap kecurangan yang terjadi disekitarnya, di dalam pengelolaan keuangan desa, pemerintah desa harus memiliki kompetensi sumber daya manusia berkualitas didukung dengan latar belakang pendidikan, pengalaman, mengikuti pelatihan, mengerti tentang akuntansi dan keuangan desa dan memahami peraturan serta prosedur mengenai pengelolaan keuangan desa beserta tujuan 
dana tersebut diberikan oleh pemerintah. Hal tersebut diperlukan agar tidak terjadi kekeliruan dalam pengelolaan keuangan desa dan ketidak sesuaian laporan yang dibuat berdasarkan standar pengelolaan keuangan yang sudah di tetapkan oleh pemerintah. Penelitian yang dilakukan oleh Laksmi et al. (2019) dan Widiyarta et al. (2017) yang menunjukkan bahwa kompetensi Pemerintah Desa berpengaruh positif terhadap pencegahan fraud dalam pengelolaan dana desa. Semakin berkompeten sumber daya manusia maka semakin tinggi pencegahan fraud dalam pengelolaan keuangan desa. Berdasarkan ulasan di atas, maka hipotesis dalam penelitian ini adalah sebagai berikut

$\mathrm{H}_{1}$ : Kompetensi sumber daya manusia berpengaruh positif terhadap pencegahan fraud dalam pengelolaan keuangan desa.

Teori keagenan berkaitan dengan Moralitas. Pemerintah Desa sebagai agent harus melaksanakan tugas dari Pemerintah pusat sebagai principal dalam melaksanakan tugas Pemerintah Desa harus mematuhi peraturan perundangundangan yang berlaku. Menurut Rahimah et al. (2018) individu yang mempunyai tingkat moral yang tinggi akan dapat mencegah terjadinya kecurangan karena individu yang mempunyai moral yang tinggi akan menaati aturan sesuai dengan prinsip-prinsip etika universal, begitupun sebaliknya, individu yang memiliki moral yang rendah cenderung membuat keputusan berdasarkan hak yang diinginkan oleh dirinya sendiri dan tidak menaati peraturan dan kewajiban yang berlaku. Dengan memiliki moral yang tinggi Pemerintah Desa akan mampu melaksanakan tugas dan tanggungjawabnya kepada Pemerintah pusat dengan baik dan benar sesuai dengan prinsip-prinsip etika universal sehingga dapat mencegah terjadinya fraud.

Moralitas dapat mempengaruhi etika atau perbuatan yang dilakukan oleh seseorang. Moralitas individu akan berhubungan pada kecenderungan seseorang untuk melakukan kecurangan akuntansi yang dinyatakan oleh Dennyningrat dan Suputra (2018). Hal ini sejalan dengan penelitian yang dilakukan oleh Wardana et al. (2017) dan Rahimah et al. (2018) yang menunjukkan bahwa moralitas berpengaruh positif terhadap pencegahan fraud dalam alokasi dana desa. Semakin tinggi moralitas yang dimiliki maka semakin tinggi pula pencegahan terhadap fraud dalam pengelolaan keuangan desa. Berdasarkan ulasan di atas, maka hipotesis dalam penelitian ini adalah sebagai berikut.

$\mathrm{H}_{2}$ : Moralitas berpengaruh positif terhadap pencegahan fraud dalam pengelolaan keuangan desa.

Pengaruh whistleblowing terhadap pencegahan fraud dalam pengelolaaan keuangan desa berkaitan dengan theory of planned behavior. Menurut Ajzen (1991), theory of planned behavior, ini didasarkan pada asumsi bahwa manusia adalah makhluk yang rasional yang akan memperhitungkan implikasi dari tindakan mereka sebelum memutuskan untuk melakukan suatu perilaku yang akan mereka lakukan. Theory of planned behaviour membuat individu takut untuk melakukan kecurangan karena merasa diawasi oleh rekannya dan takut menerima konsekuensi jika dilaporkan melakukan tindakan kecurangan, theory of planned behavior juga memotivasi individu untuk melakukan whistleblowing dalam upaya untuk menghindari kecurangan dan ditularkan kepada rekan kerjanya. Niat individu tersebut untuk menghindari kecurangan cukup kuat, sehingga memutuskan untuk tidak melakukan kecurangan (Utami et al ., 2019) 
Menurut penelitian Pamungkas et al., ( 2018), aspek-aspek dari whistleblowing system mampu menunjukkan pengaruh dari ethical behavior. Ini karena mereka merasa diawasi oleh rekan kerja mereka sendiri sehingga karyawan menjadi lebih patuh dan mematuhi kode etik yang diterapkan oleh perusahaan, dan tidak ingin melanggarnya. Semakin tinggi persepsi tentang whistleblowing system, maka mereka akan lebih patuh pada aturan-aturan yang ada di perusahaan. Hal ini, dapat mencegah terjadinya fraud pada perusahaan karena kepatuhan pada kode etik. Hasil uji hipotesis ini juga didukung oleh penelitian yang dilakukan oleh Widiyarta et al. (2017) dan penelitian Ariastini et al. (2017) yang menunjukkan bahwa whistleblowing system berpengaruh positif terhadap pencegahan fraud. Semakin efektif penggunaan whistleblowing system makan semakin tinggi pula pencegahan terhadap fraud dalam pengelolaan keuangan desa. Berdasarkan ulasan di atas, maka hipotesis dalam penelitian ini adalah sebagai berikut.

$\mathrm{H}_{3}$ : Whistleblowing system berpengaruh positif terhadap pencegahan fraud dalam pengelolaan keuangan desa.

Sistem pengendalian internal berkaitan dengan teori keaganen. Salah satu elemen kunci dari teori agensi adalah bahwa principal dan agent memiliki prefensi atau tujuan yang berbeda. Hal ini sering kali menimbulkan konflik keagenaan. Teori ini mengasumsikan bahwa tiap individu bertindak untuk kepentingan masing-masing, pengendalian dan pengawasan yang kurang baik akan menimbulkan peluang untuk terjadinya fraud (Sahesti, 2015), untuk mencegah peluang tersebut diperlukan pengendalian internal yang efektif. Pengendalian internal yang efektif akan menghasilkan informasi dan laporan bebas salah saji (Andon et al, 2015).

Sistem pengendalian merupakan suatu cara untuk mengawasi, mengarahkan serta mengukur sumber daya suatu lembaga atau organisasi serta memiliki peran yang penting didalam pencegahan dan pendeteksian adanya tindakan fraud atau kecurangan. Pengendalian internal harus memiliki kebijakan dan prosedur yang jelas yang bertujuan agar dapat menjamin dan menyediakan laporan informasi yang jelas yang bertujuan agar dapat menjamin dan menyediakan laporan informasi keuangan yang sesuai dengan prosedur yang ditetapkan (Wardani dan Andriyani, 2017). Banyaknya kasus kecurangan yang telah terbukti dipengaruhi secara langsung maupun tidak langsung karena kurangnya peringatan terhadap resiko penipuan yang ada. Karena itu, organisasi menyadari bahwa penggunaan sistem pengendalian internal akan membuat organisasi dalam mencegah fraud menjadi lebih efisien dan aman (Dragomir et al., 2015). Hal tersebut selaras dengan penelitian Ariastini et al. (2017) dan penelitian yang dilakukan oleh Laksmi et al. (2019) yang menjelaskan sistem pengendalian internal berpengaruh positif terhadap pencegahan fraud dalam pengelolaan keuangan desa. Semakin efektif sistem pengendalian internal maka semakin tinggi pula pencegahan terhadap fraud dalam pengelolaan keuangan desa. Berdasarkan ulasan di atas, maka hipotesis dalam penelitian ini adalah sebagai berikut.

$\mathrm{H}_{4}$ : Sistem pengendallian internal berpengaruh positif terhadap pencegahan fraud dalam pengelolaan keuangan desa. 


\section{METODE PENELITIAN}

Lokasi penelitian merupakan lokasi atau wilayah yang dipilih oleh peneliti untuk melakukan penelitian. Penelitian ini dilakukan di Kota Denpasar. Objek dalam penelitian ini adalah kompetensi sumber daya manusia, moralitas, whistleblowing dan sistem pengendalian internal terhadap pencegahan fraud dalam pengelolaan keuangan desa.

Pemegang kekuasaan Pelaksana Pengelolaan Keuangan Desa (PPKD) adalah Kepala Desa, Sekretaris Desa sebagai koordinator PPKD, dan Kaur Keuangan melaksanakan fungsi kebendaharaan tertuang dalam Pemendagri Nomor 20 Tahun 2018 tentang Pengelolaan Keuangan Desa. Menurut Peraturan Dalam Negeri Republik Indonesia Nomor 110 tahun 2016 tentang Badan Permusyawaratan Desa (BPD) mempunyai tugas melakukan monitoring dan evaluasi dari pelaksanaan tugas Kepala Desa. Populasi dari penelitian ini, terdiri dari Kepala Desa, Sekretaris Desa, Kaur Keuangan Desa dan Badan Permusyawaratan Desa (BPD) di 27 (dua puluh tujuh) Desa Dinas di Kota Denpasar. Pada penelitian ini, sampel yang digunakan adalah 27 Desa Dinas di Kota Denpasar. Responden dalam penelitian ini adalah Kepala Desa, Sekretaris Desa, Kaur Keuangan Desa dan Badan Permusyawaratan Desa (BPD).

Uji analisis regresi linier berganda digunakan untuk mengetahui pengaruh kompetensi sumber daya manusia, moralitas dan sistem pengendalian internal terhadap pencegahan fraud dalam pengelolaan keuangan desa secara parsial. Persamaan regresi linier berganda dapat dirumuskan sebagai berikut.

$$
Y=\alpha+\beta_{1} X_{1}+\beta_{2} X_{2}+\beta_{3} X_{3}+\beta_{4} X_{4}+\varepsilon
$$

Keterangan:

\begin{tabular}{|c|c|}
\hline $\mathrm{Y}$ & = Pencegahan Fraud dalam Pengelolaan Keuangan Desa \\
\hline$\alpha$ & $=$ konstanta \\
\hline$\beta_{1}, \beta_{2}, \beta_{3}, \beta_{4}$ & $=$ Koefisien Regresi \\
\hline $\mathrm{X}_{1}$ & $=$ Kompetensi Pemerintah Desa \\
\hline $\mathrm{X}_{2}$ & $=$ Moralitas \\
\hline $\mathrm{X}_{3}$ & $=$ Whistleblowing \\
\hline $\mathrm{X}_{4}$ & $=$ Sistem Pengendalian Internal \\
\hline & $=$ standard error \\
\hline
\end{tabular}

\section{HASIL DAN PEMBAHASAN}

Model analisis yang digunakan dalam penelitian ini adalah regresi linier berganda dengan menggunakan alat bantu berupa program SPSS versi 22. Model analisis linier berganda digunakan untuk mengetahui pengaruh kompetensi sumber daya manusia, moralitas dan sistem pengendalian internal terhadap pencegahan fraud dalam pengelolaan keuangan desa di Kota Denpasar. Dalam model analisis regresi linier berganda yang digunakan sebagai variabel bebas (independen) adalah kompetensi sumber daya manusia, moralitas dan sistem pengendalian internal sedangkan variabel terikat (dependen) adalah pencegahan fraud dalam pengelolaan keuangan desa. Hasil rangkuman analisis regresi dapat dilihat pada Tabel 1 berikut: 
Tabel 1. Hasil Uji Regresi Linier Berganda

\begin{tabular}{|c|c|c|c|c|c|}
\hline \multirow[t]{2}{*}{ Model } & \multicolumn{2}{|c|}{$\begin{array}{l}\text { Unstandardized } \\
\text { Coefficients }\end{array}$} & \multicolumn{2}{|c|}{$\begin{array}{r}\text { Standardized } \\
\text { Coefficients }\end{array}$} & \multirow[b]{2}{*}{ Sig } \\
\hline & B & Std. Error & Beta & $\mathrm{t}$ & \\
\hline (Constant) & $-1,681$ & 0,853 & & $-1,971$ & 0,051 \\
\hline $\begin{array}{l}\text { Kompetensi Sumber } \\
\text { Dava Manusia }\left(X_{1}\right)\end{array}$ & 0,179 & 0,043 & 0,254 & 4,186 & 0,000 \\
\hline Moralitas $\left(X_{2}\right)$ & 0,331 & 0,074 & 0,237 & 4,493 & 0,000 \\
\hline Whistleblowing $\left(\mathrm{X}_{3}\right)$ & 0,333 & 0,049 & 0,372 & 6,725 & 0,000 \\
\hline $\begin{array}{l}\text { Sistem Pengendalian } \\
\text { Internal }\left(X_{4}\right)\end{array}$ & 0,125 & 0,036 & 0,199 & 3,469 & 0,001 \\
\hline $\mathrm{R}^{2}$ & $=0,873$ & & & & \\
\hline $\begin{array}{l}\text { Adjusted R Square } \\
\text { F hitung }\end{array}$ & $=0,868$ & & & & \\
\hline F hitung & $=177,305$ & & & & \\
\hline
\end{tabular}

Sumber: Data Penelitian, 2019

Berdasarkan Tabel 1. maka, persamaan regresi dan arti dalam persamaan regresi yang digunakan dalam penelitian adalah sebagai berikut.

$$
\mathrm{Y}=-1,681+0,179 \mathrm{X}_{1}+0,331 \mathrm{X}_{2}+0,333 \mathrm{X}_{3}+0,125 \mathrm{X}_{4}
$$

Persamaan regresi (2) menunjukkan bahwa nilai konstantan (a) menunjukkan nilai positif sebesar 3,005 yang memiliki arti bahwa variabel kompetensi sumber daya manusia $\left(X_{1}\right)$, moralitas $\left(X_{2}\right)$, whistleblowing $\left(X_{3}\right)$, dan sistem pengendalian internal $\left(\mathrm{X}_{4}\right)$ dinyatakan konstan pada angka 0 , maka pencegahan fraud dalam pengelolaan keuangan desa adalah baik. Variabel kompetensi sumber daya manusia $\left(X_{1}\right)$ memiliki koefisien beta bernilai positif sebesar 0,179 yang berarti, variabel kompetensi sumber daya manusia memiliki pengaruh positif terhadap pencegahan fraud dalam pengelolaan keuangan desa. Variabel moralitas $\left(X_{2}\right)$ memiliki koefisien beta bernilai positif sebesar 0,331 yang berarti, variabel moralitas memiliki pengaruh positif terhadap pencegahan fraud dalam pengelolaan keuangan desa. Variabel whistleblowing $\left(X_{3}\right)$ memiliki koefisien beta bernilai positif sebesar 0,333 yang berarti, variabel whistleblowing $\left(X_{3}\right)$ memiliki pengaruh positif terhadap pencegahan fraud dalam pengelolaan keuangan desa. Variabel sistem pengendalian internal $\left(\mathrm{X}_{4}\right)$ memiliki koefisien beta bernilai positif sebesar 0,125 yang berarti, variabel sistem pengendalian internal memiliki pengaruh positif terhadap pencegahan fraud dalam pengelolaan keuangan desa.

Hasil analisis regresi menunjukkan bahwa nilai Adjusted $R$ Square pada Tabel 1. halaman 61, sebesar 0,418. Hal ini berarti, pencegahan fraud dalam pengelolaan keuangan desa dapat dijelaskan oleh variabel kompetensi sumber daya manusia, moralitas dan sistem pengendalian internal sebesar 0,418 atau 41,8 persen sedangkan 0,582 atau 58,2 persen dijelaskan oleh faktor-faktor lain yang tidak diuji dalam penelitian ini.

Uji F atau uji kelayakan model digunakan untuk melihat apakah semua variabel bebas (independen) mempunyai pengaruh secara simultan terhadap variabel terikat (dependen) dengan tingkat signifikansi $a=0,05$. Apabila tingkat signifikansi $\mathrm{F} \leq \mathrm{a}=0,05$ maka model ini dikatakan layak uji. Sebaliknya, jika tingkat signifikansi $\mathrm{F}>\mathrm{a}=0,05$ maka model persamaan regresi dapat dikatakan tidak layak uji (Ghozali, 2016:96). Berdasarkan hasil penelitian uji $\mathrm{F}$ pada Tabel 4.10 halaman 61, dapat dilihat bahwa nilai signifikansi sebesar 0,000 $\leq 0,05$. Hal 
ini menunjukkan bahwa semua variabel bebas berpengaruh secara simultan terhadap variabel terikat dan model regresi ini layak digunakan.

Hipotesis satu $\left(\mathrm{H}_{1}\right)$ menyatakan bahwa kompetensi sumber daya manusia berpengaruh positif terhadap pencegahan fraud dalam pengelolaan keuangan desa. Hasil uji hipotesis yang telah dilakukan menunjukkan bahwa, kompetensi sumber daya manusia berpengaruh positif terhadap pencegahaan fraud dalam pengelolaan keuangan desa. Hal ini berarti, semakin berkompeten sumber daya manusia maka akan semakin tinggi pula pencegahan fraud dalam pengelolaan keuangan desa. Hasil uji ini juga didukung oleh dengan teori keagenan. Teori keagenan memiliki prinsip utama berupa hubungan kerja antara dua pihak yaitu pihak yang memberikan wewenang (principal) dengan pihak yang menerima wewenang (agent) dalam suatu bentuk kerja sama yang dinamakan dengan "nexus of contract" (Jensen and Meckling, 1976). Pemerintah pusat yang mewakili rakyat sebagai principal diasumsikan hanya tertarik kepada laporan keuangan yang angka-angka di pos pembelanjaan sesuai dengan angka-angka yang diajukan dalam proposal dana desa, sementara pihak pemerintah desa sebagai agen akan berusaha menyajikan laporan keuangan yang sesuai dengan keinginan pemerintah pusat agar di masa mendatang bisa kembali memperoleh dana karena laporan keuangan memenuhi syarat (Murthy dan Jack, 2017). Kompetensi sumber daya manusia yang berkualitas dari Pemerintah Desa sangat dibutuhkan dalam melaksanakan tanggungjawab tersebut, khususnya dalam pengelolaan keuangan desa, schingga penggunaan dan pertanggungjawaban dalam pengelolaan keuangan desa sesuai dengan Undang-undang Nomor 6 Tahun 2014 Tentang Desa dan Peraturan Menteri Dalam Negeri Nomor 20 Tahun 2018 tentang Pengelolaan Keuangan Desa.

Hasil ini juga didukung oleh Sugiarti dan Yudianto (2017) menjelaskan bahwa kompetensi sumber daya manusia mencakup kapasitasnya yaitu kemampuan seorang individu, suatu organisasi (kelembagaan) atau suatu sistem untuk melaksanakan fungsi-fungsi atau kewenangannya untuk mencapai tujuannya secara efektif dan efisien. Kapasitas harus dilihat sebagai kemampuan untuk mencapai kinerja, menghasilkan output dan income. Jika seseorang memiliki keterampilan, pengetahuan, dan kemampuan yang memadai biasanya mudah mendeteksi adanya kecurangan yang terjadi karena dengan memiliki pengetahuan yang lebih atau melebihi orang yang melakukan fraud, seseorang akan lebih peka terhadap kecurangan yang terjadi disekitarnya, di dalam pengelolaan keuangan desa, pemerintah desa harus memiliki kompetensi sumber daya manusia berkualitas didukung dengan latar belakang pendidikan, pengalaman, mengikuti pelatihan, mengerti tentang akuntansi dan keuangan desa dan memahami peraturan serta prosedur mengenai pengelolaan keuangan desa beserta tujuan dana tersebut diberikan oleh pemerintah. Hal tersebut diperlukan agar tidak terjadi kekeliruan dalam pengelolaan keuangan desa dan ketidak sesuaian laporan yang dibuat berdasarkan standar pengelolaan keuangan yang sudah di tetapkan oleh Pemerintah. Penelitian yang dilakukan oleh Laksmi et al . (2019) dan Widiyarta et al. (2017) yang menunjukkan bahwa kompetensi pemerintah desa berpengaruh positif terhaadap pencegahan fraud dalam pengelolaan dana desa. 
Hipotesis dua $\left(\mathrm{H}_{2}\right)$ menyatakan bahwa moralitas berpengaruh positif terhadap pencegahan fraud dalam pengelolaan keuangan desa. Berdasarkan hasil uji hipotesis yang dilakukan menunjukkan bahwa, moralitas berpengaruh positif terhadap pencegahan fraud dalam pengelolaan keuangan desa. Hal ini berarti, semakin tinggi moralitas yang dimiliki maka semakin tinggi pula pencegahan terhadap fraud dalam pengelolaan keuangan desa.

Hasil penelitian ini didukung dengan teori keagenan. Pemerintah Desa sebagai agent harus melaksanakan tugas dari Pemerintah pusat sebagai principal dalam melaksanakan tugas Pemerintah Desa harus mematuhi peraturan perundang-undangan yang berlaku. Penelitian Rahimah et al. (2018) juga mendukung dengan menjelaskan bahwa individu yang mempunyai tingkat moral yang tinggi akan dapat mencegah terjadinya kecurangan karena individu yang mempunyai moral yang tinggi akan menaati aturan sesuai dengan prinsipprinsip etika universal, begitupun sebaliknya, individu yang memiliki moral yang rendah cenderung membuat keputusan berdasarkan hak yang diinginkan oleh dirinya sendiri dan tidak menaati peraturan dan kewajiban yang diinginkan oleh dirinya. Dengan memiliki moral yang tinggi pemerintah Desa akan mampu melaksanakan tugas dan tanggungjawabnya kepada Pemerintah pusat dengan baik dan benar sesuai dengan prinsip-prinsip etika universal sehingga dapat mencegah terjadinya fraud. Moralitas dapat mempengaruhi etika atau perbuatan yang dilakukan oleh seseorang. Moralitas individu akan berhubungan pada kecenderungan seseorang untuk melakukan kecurangan akuntansi yang dinyatakan oleh Dennyningrat dan Suputra (2018). Hal ini didukung dengan penelitian yang dilakukan oleh Wardana et al. (2017) dan Rahimah et al., (2018) yang menunjukkan bahwa moralitas berpengaruh positif terhadap pencegahan fraud dalam alokasi dana desa.

Hipotesis tiga $\left(\mathrm{H}_{3}\right)$ menyatakan bahwa whistleblowing berpengaruh positif terhadap pencegahan fraud dalam pengelolaan keuangan desa. Hasil uji hipotesis yang dilakukan menunjukkan bahwa whistleblowing berpengaruh positif terhadap pencegahan fraud dalam pengelolaan keuangan desa. Hal ini berarti semakin efektif penggunaan whistleblowing system makan semakin tinggi pula pencegahan terhadap fraud dalam pengelolaan keuangan desa. Hal tersebut didukung oleh theory of planned behaviour. Menurut Ajzen (1991), theory of planned behavior, ini didasarkan pada asumsi bahwa manusia adalah makhluk yang rasional yang akan memperhitungkan implikasi dari tindakan mereka sebelum memutuskan untuk melakukan suatu perilaku yang akan mereka lakukan. Theory of planned behaviour memotivasi individu untuk melakukan whistleblowing dalam upaya untuk menghindari kecurangan dan ditularkan kepada rekan kerjanya. Niat individu tersebut untuk menghindari kecurangan cukup kuat, sehingga memutuskan untuk tidak melakukan kecurangan (Utami et al., 2019).

Penelitian yang mendukung penelitian dari Pamungkas et al., ( 2018), aspek-aspek dari whistleblowing system mampu menunjukkan pengaruh dari ethical behavior. Ini karena mereka merasa diawasi oleh rekan kerja mereka sendiri sehingga karyawan menjadi lebih patuh dan mematuhi kode etik yang diterapkan oleh perusahaan, dan tidak ingin melanggarnya. Semakin tinggi persepsi tentang whistleblowing system, maka mereka akan lebih patuh pada aturan-aturan yang ada di perusahaan. Hal ini, dapat mencegah terjadinya fraud 
pada perusahaan karena kepatuhan pada kode etik. Hasil Penelitan yang mendukung adalah Penelitian oleh Widiyarta et al. (2017) dan Ariastini et al. (2017) yang menunjukkan bahwa whistleblowing system berpengaruh positif signifikan terhadap pencegahan fraud.

Hipotesis tiga $\left(\mathrm{H}_{4}\right)$ menyatakan bahwa sistem pengendalian internal berpengaruh positif terhadap pencegahan fraud dalam pengelolaan keuangan desa. Hasil uji hipotesis yang dilakukan menunjukkan bahwa sistem pengendalian internal berpengaruh positif terhadap pencegahan fraud dalam pengelolaan keuangan desa. . hal ini berarti, Semakin efektif sistem pengendalian internal maka semakin tinggi pula pencegahan terhadap fraud dalam pengelolaan keuangan desa.

Hal tersebut didukung oleh teori keaganen, salah satu elemen kunci dari teori agensi adalah bahwa principal dan agent memiliki prefensi atau tujuan yang berbeda. Hal ini sering kali menimbulkan konflik keagenaan. Teori ini mengasumsikan bahwa tiap individu bertindak untuk kepentingan masingmasing, pengawasan yang kurang baik akan menimbulkan peluang terjadinya fraud, Kualitas pengawasan yang baik akan meminimalisasi peluang terjadinya kecurangan.(Sahesti, 2015). Sistem pengendalian internal yang efektif sangat dibutuhkan karena akan mengurangi kesempatan untuk melakukan kecurangan sehingga dapat mencegah terjadinya fraud.

Sistem pengendalian merupakan suatu cara untuk mengawasi, mengarahkan serta mengukur sumber daya suatu lembaga atau organisasi serta memiliki peran yang penting di dalam pencegahan dan pendeteksian adanya tindakan fraud atau kecurangan. Pengendalian internal harus memiliki kebijakan dan prosedur yang jelas yang bertujuan agar dapat menjamin dan menyediakan laporan informasi yang jelas yang bertujuan agar dapat menjamin dan menyediakan laporan informasi keuangan yang sesuai dengan prosedur yang ditetapkan (Wardani dan Andriyani, 2017). Banyaknya kasus kecurangan yang telah terbukti dipengaruhi secara langsung maupun tidak langsung karena kurangnya peringatan terhadap resiko penipuan yang ada. Karena itu, organisasi menyadari bahwa penggunaan sistem pengendalian internal akan membuat organisasi dalam mencegah fraud menjadi lebih efisien dan aman (Dragomir et al., 2015). Hal tersebut didukung dengan penelitian Ariastini et al. (2017) dan penelitian yang dilakukan oleh Laksmi et al . (2019) yang menjelaskan sistem pengendalian internal berpengaruh positif terhadap pencegahan fraud dalam pengelolaan keuangan desa

\section{SIMPULAN}

Kompetensi sumber daya manusia berpengaruh positif terhadap pencegahan fraud dalam pengelolaan keuangan desa. Moralitas berpengaruh positif terhadap pencegahan fraud dalam pengelolaan keuangan desa. Whistleblowing berpengaruh positif terhadap pencegahan fraud dalam pengelolaan keuangan desa. Sistem pengendalian internal berpengaruh positif terhadap pencegahan fraud dalam pengelolaan keuangan desa. 


\section{REFERENSI}

Adi, M. R. K., Ardiyani, K. \& Ardianingsih, A. (2016). Analisis Faktor-Faktor Penentu Kecurangan (Fraud) pada Sektor Pemerintahan (Studi Kasus pada Dinas Pendapatan Pengelolaan Keuangan dan Aset Daerah Kota Pekalongan). Jurnal Litbang Kota Pekalongan, 10, 1-10.

Agusyani, K. S., Sujana, E. \& Wahyuni, M. A. (2016). Pengaruh Whistleblowing System dan Kompetensi Fraud Pada Pengelolaan Keuangan Penerimaan Pendapatan Asli Daerah ( Studi Pada Dinas Pendapatan Daerah Kabupaten Buleleng ). E-Jurnal S1 Ak Universitas Pendidikan Ganesha, 6(3).

Aini, N., Prayudi, M. A., Diatmika, P. G. \& Ganesha, U. P. (2017). Pengaruh Perspektif Fraud Diamond Terhadap Kecenderungan Terjadinya Kecurangan ( Fraud ) Dalam Pengelolaan Keuangan Desa. E-Jurnal S1 Ak Universitas Pendidikan Ganesha, 8(2).

Ajzen, I. (1991). The Theory of Planned Behavior. Journal of Organizational Behaviour and Human Decision Processes, 50, 179-211.

Andon, P., Free, C. \& Scard, B. (2015). Pathways to Accountant Fraud : Australian Evidence and Analysis Article Information: Accounting Research Journal, 22(1).

Ariastini, N. K. D., Yuniarta, G. A. \& Kurniawan, P. S. (2017). Pengaruh Kompetensi Sumber Daya Manusia, Sistem Pengendalian Internal Pemerintah , Proactive Fraud Audit, Dan Whistleblowing System Terhadap Pencegahan Fraud Pada Pengelolaan Dana Bos Se-Kabupaten Klungkung. E-Journal S1 Ak Universitas Pendidikan Ganesha.

Azlina, N., Hasan, A., Desmiyawati \& Muda, I. (2017). The Effectiveness of Village Fund Management (Case Study at Villages in Coastal Areas in Riau). International Journal of Economic Research, (January).

BPKP. (2018). Laporan Hasil Pengawasan Di Wilayah Provinsi Bali 2017.. http://www.bpkp.go.id/public/upload/unit/bali/files/File\%20Update/ 2019/Lap\%20Keuangan\%202018.pdf. Diakses 25 Juli 2019.

Committee of Sponsoring Organizations of the Treadway Commission (COSO). (2019). Internal Control-Integrated Framework. New York: AICPA.

Dennyningrat, I. G. A. G. \& Suputra, I. D. G. D. (2018). Pengaruh Sistem Pengendalian Intern Pemerintah dan Moralitas Individu Pada Kesalahan Akuntansi. E-Jurnal Akuntansi Universitas Udayana, 22(2), 1170-1196.

Donelson, D. C., Ege, M., \& Mclnnis, J. M. (2015). Internal Control Weaknesses and Financial Reporting Fraud Dain. Auditing: A Journal of Practice $\mathcal{E}$ Theory, Forthcoming.

Ferina, I. S., Burhanuddin, \& Lubis, H. (2014). Tinjauan Kesiapan Pemerintah Desa Dalam Implementasi Peraturan Menteri Dalam Negeri Nomor 113 Tahun 2014 Tentang Pengelolaan Keuangan Desa (Studi Kasus pada Pemerintah Desa di Kabupaten Ogan Ilir). Jurnal Manajemen Dan Bisnis Sriwijaya, 14(3), 321-336.

Hoi, C. \& Robin, A. (2010). Labor Market Consequences of Accounting Fraud Labor Market Consequences of Accounting Fraud. Journal of Rochester Institute of Technology, 10(03), 321-333.

Ikatan Akuntan Indonesia (IAI). (2001). Pertimbangan Atas Kecurangan Dalam Audit Laporan Keuangan SA Seksi 316. Jakarta: DSAK-IAI.. 
Indonesia Corruption Watch (ICW). (2018). https://nasional.kompas.com/read/2018/09/18/15475381/catatan-icwsoal-penindakan-kasus-korupsi-semester-i-2018. Diakses 28 Juli 2019.

Jensen, M. C. \& Meckling, W. H. (1976). Theory of The Firm: Managerial Behavior, Agency Costs and Ownership Structure. Journal of Financal Economics, 3, 305-360.

Joseph, O. N., Albert, O. \& Byaruhanga, P. J. (2015). Effect of Internal Control on Fraud Detection and Prevention in District Treasuries of Kakamega County. International Journal of Business and Management Invention, 4(1), 4757

Kern, S. M., \& Weber, G. J. (2016). Implementing a "real-world" Fraud Investigation Class: The Justice for Fraud Victims Project. Issues in Accounting Education. https:// doi.org/10.2308/iace-51287.

Kompas.com. (2019). Bongkar Dugaan Korupsi Dana Desa, Kejari Denpasar Periksa $12 \quad$ Saksi. https:/ /regional.kompas.com/read/2019/06/25/12044671/bongkardugaan-korupsi-dana-desa-kejari-denpasar-periksa-12-saksi. Diakses 25 Juli 2019.

Laksmi, P. S. P., \& Sujana, I. K. (2019). Pengaruh Kompetensi SDM, Moralitas dan Sistem Pengendalian Internal Terhadap Pencegahan Fraud Dalam Pengelolaan Keuangan Desa. E-Jurnal Akuntansi Universitas Udayana, 26(3), 2155-2182.

Lane, J. E. (2013). The Principal-Agent Approach to Politics: Policy Implementation and Public Policy-Making. Open Journal of Political Science, $3(2), 85-89$.

Manosoh, H. (2016). A Number of Factors that Cause Fraud at The Government of North Sulawesi Province. Jurnal Akuntansi Universitas Sam Ratulangi Manado, 4(1), 484-495.

Murphy, P. R., \& Free, C. (2016). Broadening the Fraud Triangle: Instrumental Climate and Fraud. Journal of Behavioral Research in Accounting.

Murthy, D. N. P. \& Jack, N. (2017). Game Theoretic Modelling of Service Agent Warranty Fraud. Journal of the Operational Research Society.

Pamungkas, I. D., Ghozali, I. \& Achmad, T. (2018). The Effects of The Whistleblowing System on Financial Statement Fraud Ethical Behavior as The Mediators. International Journal of Civil Engineering and Technology.

Peraturan Menteri Dalam Negeri Nomor 110 tahun 2016 tentang Badan Permusyawaratan Desa (BPD)

Peraturan Menteri Dalam Negeri Nomor 20 Tahun 2018 tentang Pengelolaan Keuangan Desa.

Peraturan Pemerintah Nomor 60 tahun 2008 tentang Sistem Pengendalian Internal Pemerintah (SPIP).

Rahimah, L. N., Murni, Y., \& Lysandra, S. (2018). Pengaruh Penyajian Laporan keuangan Desa, Lingkungan Pengendalian dan Moralitas Individu Terhadap Pencegahan Fraud yang Terjadi dalam Pengelolaan Alokasi Dana Desa. Jurnal Ilmiah Ilmu Ekonomi, 6(12), 139-154. 
Sahesti, I. G. A. (2015). Pengaruh Corporate Governance Dan Kualitas Internal pada Perusahaan Manufaktur di Bursa Efek Indonesia Tahun 2011-2013. EJurnal Fakultas Ekonomi UMP, 1-16.

Setiawan, S. (2018). The Effect of Internal Control And Individual Morality on The Tendency Of Accounting Fraud. Asia Pasific Fraud Journal, 3(1), 33-41. https:// doi.org/10.21532/apfj.001.18.03.01.04

Sugiarti, E., \& Yudianto, I. (2017). Analisis Faktor Kompetensi Sumber Daya Manusia , Pemanfaatan Teknologi Informasi, dan Partisipasi Penganggaran Terhadap Akuntabilitas Pengelolaan Dana Desa ( Survei Pada Desa-Desa di Wilayah Kecamatan Klari , Kecamatan Karawang Timur , Kecamatan Majalaya. Jurnal Akuntansi Universitas Padjajaran.

Undang-undang Republik Indonesia Nomor 13 Tahun 2003 Tentang Ketenagakerjaan.

Undang-Undang Republik Indonesia Nomor 5 Tahun 2014 tentang Aparatur Sipil Negara.

Utami, L., Handajani, L. \& Hermanto. (2019). Efektivitas Komite Audit dan Audit Internal terhadap Kasus Kecurangan dengan Whistleblowing System sebagai Variabel Pemoderas. E-Jurnal Akuntansi Universitas Udayana, 26(2), 1570-1600.

Wardana, I. G. A. K., Sujana, E. \& Wahyuni, M. A. (2017). Pengaruh Pengendalian Internal, Whistleblowing System dan Moralitas Aparat Terhadap Pencegahan Fraud Pada Dinas Pekerjaan Umum Kabupaten Buleleng. E-Journal S1 Ak Universitas Pendidikan Ganesha, 8(2).

Wardani, D. K. \& Andriyani, I. (2017). Pengaruh Kualitas Sumber Daya Manusia, Pemanfaatan Teknologi Informasi, dan Sistem Pengendalian Intern Terhadap Keandalan Pelaporan Keuangan Pemerintahan Desa di Kabupaten Klaten. Jurnal Akuntansi Universitas Sarjanawiyata Tamansiswa, 5(2), 88-98.

Widiyarta, K., Herawati, N. T. \& Atmadja, A. T. (2017). Pengaruh Kompetensi Aparatur, Budaya Organisasi, Whistleblowing dan Sistem Pengendalian Internal Terhadap Pencegahan Fraud Dalam Pengelolaan Dana Desa (Studi Empiris Terhadap Pemerintah Desa di Kabupaten Buleleng). E-Jurnal Akuntansi Universitas Pendidikan Ganesha, 8(2).

Yang, D., Jiao, H., \& Buckland, R. (2017). The Determinants of Financial Fraud in Chinese firms: Does Corporate Governance as an Institutional Innovation Matter. Technological Forecasting and Social Change. 